International Journal of Language Education

Volume 4, Number 2, 2020, pp. 258-275

ISSN: 2548-8457 (Print) 2548-8465 (Online)

Doi: https://doi.org/10.26858/ijole.v4i2.13980

\title{
Non-Native Arabic Learners' Social Media Usage and Motivation Influencing Learning of Arabic Language in Malaysian Public Universities
}

\author{
Di Xuan \\ PhD student in Faculty of Education, University of Malaya \\ Email:dixuan198911@gmail.com \\ Wail Muin Ismail \\ Lecturers in Faculty of Education, University of Malaya. \\ Email:wailismail@um.edu.my \\ Muhammad Azhar Zailani \\ Lecturers in Faculty of Education, University of Malaya. \\ Email:azhar@um.edu.my
}

Received: 13 June 2020

Reviewed: From 1 August 2020 to 17 September 2020

Accepted: 1 October 2020

\begin{abstract}
This paper aims to clarify the concepts related to the use of social media usage and motivation and their effect on the learning of a new language. They have also investigated the relationship between these variables and determined the influence of motivation and SMU on the academic performance of the students. For this purpose, quantitative survey was employed by distributed questionnaires which adopted from Monachesi et al. (2008) data language technologies for lifelong learning along with the Motivated Strategies for Learning Questionnaires (MSLQ) amongst 317 Arabic learners to six selected universities. They carried out quantitative data analysis by using SPSS and SmartPLS. The finding reported that these learners SMU displayed a significant correlation with motivation. A variation in the results was noted according to the year of study for all the learners. Furthermore, the results indicated that self-efficacy showed a varying effect on the academic performance of the students. The researchers discussed the results related to the learning of a language and the educational practices which were implemented. The results of this study could benefit the instructors, faculty and the student population.
\end{abstract}

Keywords: Social media usage, Motivation, Language learning strategies, Arabic language Education 


\section{Introduction}

Arabic language education was emphasized due to its religious role in Malaysia, and the Arabic language has an even greater effect on its speakers than other languages have on their speakers (Morrow and Castleton 2007). Many historical documents have stated that the Arabic language was introduced in Malaysia by the Yemeni merchants arriving in Malacca during the $13^{\text {th }}$ century. Thereafter, when the Sultan of Malacca converted to Islam, the number of Arabic migrants entering the city increased. This trend was noted until the $20^{\text {th }}$ century. According to Ismail (1993), no clear trend could be noted with regards to the development of the learning and teaching of the Arabic language in Malaysia, however, many researchers have presumed that this trend developed immediately after the introduction of the Islam religion in the country, i.e., during the $14^{\text {th }}$ and $15^{\text {th }}$ century. In the beginning, these Arabic teaching lessons only focused on imparting the knowledge of Islam to the masses.

There are seven types for the teaching of Arabic in Malaysia since earlier times. As displayed in Fig. 1. The primary form of Arabic teaching and learning was known as "Halaqah" and "Pondok". In this system, the students have to sit on the floor of the teacher's house, or mosque or a small prayer room called "Surau", to form a semi-circle or a full circle. This system curriculum encouraged the students to read the Quran, and also included lessons related to the religious knowledge, moral teachings, Arabic language and Bahasa Malayu. Thereafter, the Sekolah Ugama/ Sekolah Arab/ Madrasah was established for formally teaching or learning the Arabic language. The Arabic language was used the medium of instruction only while teaching the Arabic language, while other religious subjects were taught using the Malay language.

With regards to the different teaching methodologies used, these schools implemented the teaching methods which were similar to those used in Arabic schools. Here, the lessons related to grammar, reading or writing along with dictation were taught separately by explaining the rules and translating the vocabulary. The difference between the teaching methods used in Arabic schools and these schools was that the Malay language was frequently used in these new schools (Ismail 1993). Currently, the students who graduate from the religious Malaysian schools can avail many opportunities related to their higher education, like Islamic colleges and universities, or they can pursue their higher education in other Arabic countries like Egypt, Jordan and Morocco (Jordan Times 2010; Ataaleem 2017).

Types of teaching and learning Arabic in Malaysia

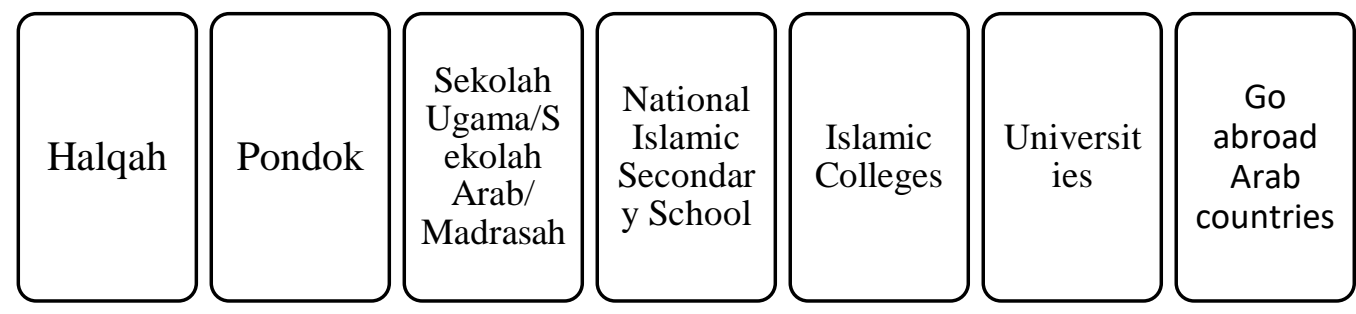

Figure 1: The Types of teaching and learning Arabic in Malaysias 
Many studies claim that the teaching and learning the Arabic language as a third language have yet to achieve its intended target (Ainon and Abdullah, 2005). Several empirical studies Ghani et al., 2011; Awang, Mohamed \& Sulaiman, 2013) have concluded that university-level Malay learners are weak in their ability to communicate in the Arabic language. In case to find out the problems may cause students weak in oral speaking, some researchers focus on language learning strategies (Haron et al., 2010; Yusri et al., 2012); some focus on motivation (Ghenghesh, 2010; Bakar, Sulaiman \& Rafaai, 2010).

Many factors that contribute to this situation have been identified. Firstly, it is clear that the language learning environment would significantly cause learners to be weak in Arabic oral speaking. However, some studies found that students could be good Arabic speakers while being in a non-native speaking environment (Haron et al., 2010; Yusri et al., 2012). On the other hand, Haron et al., (2010) argued that the students may lack the strategies required for Arabic language learning. The researcher believes that being aware of language learning strategy use will enhance learners' speaking skills and assist learners in becoming good Arabic speakers rather than relying solely on the learning environment. Thus, the researcher noted that there is a need to further examine self-regulated learning strategies among Arabic learners and the influence of those strategies on Arabic performance.

\section{Literature Review}

Social media as a learning tool (SMLT)

Currently, many researchers have investigated the effect of social media usage as all college students make use of this technology. Earlier studies indicated that college students used social media networks for either contacting their friends and families, studying or watching videos. Increasing use of social media networks was attributed to the Blended Learning Environments (BLE) in higher education (2017; 2018; 2019). Furthermore, the "incorporation of mobile devices in teaching and learning" was seen to be one of the Top 10 Strategic Technologies used in 2019. The use of social media technology as a learning tool is widespread. Though some people worry about the negative effect of the social media usage, it has been noted that the actual effect of the integration of this technology in the teaching methods is based on how the students use it. Students need skills in controlling learning through multiple information and technology to avoid addictive in entertainment (Junco et al., 2013). In their study, Sehatzadeh and Sheffield (2014) stated that a majority of the teachers $(62.63 \%)$ were not agreeable to the use of social media tools. This response was similar to the response obtained from the students $(66.32 \%)$. Furthermore, $37 \%$ of the students stated that they often got distracted while using social media during class (Brooks and Pomerantz 2017). This topic of using social media tools for learning is a very controversial issue. The researchers believed that the use of social media tools would only increase constantly amongst the college or university students since these tools enhance the undergraduate learning experience. These tools help the students collaborate with each other for creating online documents, share information online, manage and track their academic schedules, build good relationships with their peers, post/repost information or media found online, create media for sharing it online, 
comment on the online data or media. These activities fulfil the student and faculty needs for developing $21^{\text {st }}$-century skills amongst the students (Smith 2017). Chawinga reported in 2017, if properly prepared, Twitter and blogs will promote a student-led approach to teaching, because using these technologies, students can be found collaboration and discussing course materials, expressing their opinions, and among themselves and with lecturers Interacted.

Smith (2017) described several categories for social media related to the undergraduate learning like Google Apps (i.e., Google Calendar, Google Docs), File sharing (i.e., Google Drive, Dropbox, BitTorrent), Social networking (like Facebook Video sharing, YouTube or Vine), VOIP/instant messaging (i.e., Skype, Google Talk/Chat), Wikis (such as Wikipedia, Wikimedia), Image sharing (like Instagram, Flickr, Pinterest), Location-based apps (like Foursquare, Google Maps), Blogs (like Blogger, WordPress), Microblogs (Twitter) or various social news sites (like Reddit).

Why use Social media in language learning?

1. Break traditional language learning methods and realize for Student-led learning. It is widely accepted by college university students (Chawinga, 2017; Google (Firm) Canvas8 (Firm), 2019)

2. Language learners are vary in learning styles, which involved Visual learners, Aural learners, Verbal (linguistic), Logical (mathematical), Social, Solitary, and Physical learners. This definition was typically grounded from Gardner's (2006) multiple intelligences and education. Social media can meet the requirements of students with different learning styles (KeHua, 2016).

3. Ubiquitous Learning environment, and easy to operate (KeHu, 2016)

4. Develop language learners SRL, motivation, Collaboration learning, and intercultural communication competence with native speaker (Dabbagh \& Kitsantas, 2012; Tu, Yen \& Sujo-Montes, 2015; Matzat \& Vrieling, 2019; Google (Firm) Canvas8 (Firm), 2019; Akbari, Naderi, Simons \& Pilot, 2016).

5. Social media is powerful technical, whereby assist for improve language learning skills. Able to improve language learners listening, Speaking, Reading, Writing, translating, pragmatic competence, and cross-culture skills (KeHua, 2016). As displayed in Figure 2.

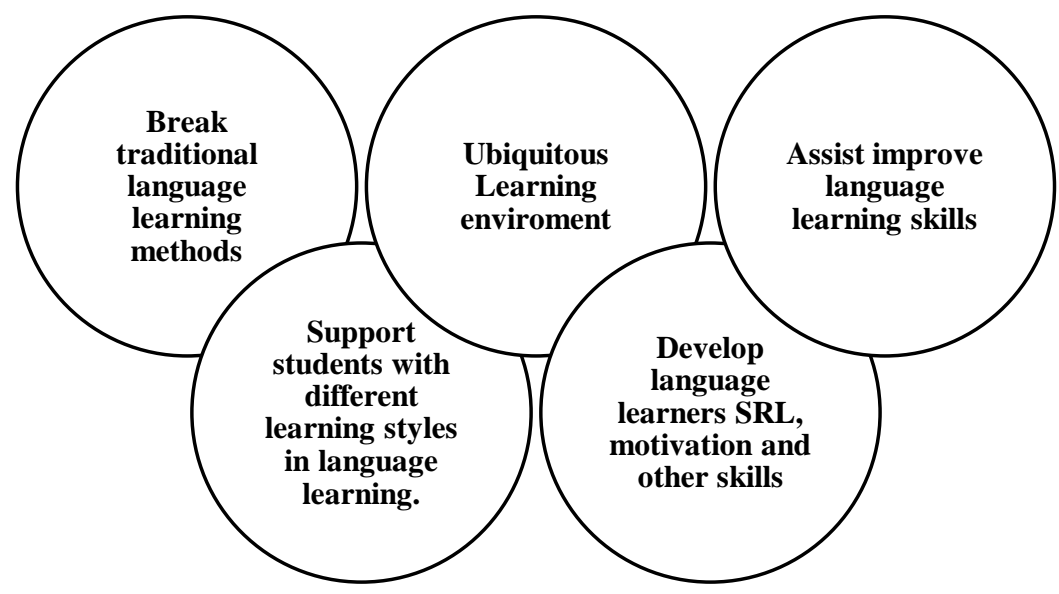

Figure 2: Why use Social media in language learning 
Motivation and Second Language Acquisition (SLA)

Motivation refers to the internal drive which encourages any learner to pursue a series of activities. It initiates learning in the students and acts as a driving force so that the students sustain their learning process over the several years needed for learning a new language. Dörnyei (2008) stated that in the absence of appropriate motivation, no single factor can ensure student achievements. A huge number of studies highlighted the essential role of Motivation towards language learning (Dörnyei and Ushioda 2013).

Why motivation is vital for language learning?

There are two main reasons have been given by Dörnyei (2014) for this considerable attention to language learning motivation: Firstly, motivation offers a basic impetus for initiating the learning of a foreign language. Thereafter, it acts as a driving force which helps the learners sustain the tedious learning procedure. All additional factors related to the learning of a foreign language are based on motivation to a certain extent. Secondly, motivation helps in overcoming the limitations noted in the language learning and aptitude of the students. Hence, even if the language aptitude is responsible for a large proportion of the learner's variability during learning a language, the motivational factors can help them overcome the effect of aptitude.

Social Media, Motivation and Learning Performance

According to Ball-Rokeach (2008) Media system dependency theory (MSD) as social, media and audience are in interdependence relation. And cognitive, affective and behavioral directly influence in society and media, society and media indirectly influence in cognitive, affective and behavioral. As Ziegler (2007) reported that "SNSs have the capacity to radically change the educational system... and to better motivate students as engaged learners" Thus, the researchers assumed social media usage indirect effect on motivation, and motivation direct effect on social media usage.

Akbari et al. (2016) stated that the students who joined Facebook Groups showed a better TOEFL post-test result compared to the Face-To-Face (FTF) groups. The Facebook groups showed a higher engagement and motivation level after the completion of the group compared to the FTF groups. Bugeja (2006) suggested that informal activities in SNSs may allow the opportunity to re-engage learners with formal education and learning promoting in learners critical thinking about their learning process. Malerba (2015) reported in study, virtual communities and platforms reproducing the social qualities of SNSs there is some potential for students to learn from informal communication and interactions. Empirical studies have been proved that social media enhance language learning and improve learners' motivation. By the same taken, Karbakhsh and Safa (2020) investigated about L2 achievement and goal orientation, self-efficacy which are dimensions motivation. The results revealed that language learning motivation predicted students' language learning achievement. On the other hand, Xuan et al. (2014) reported academic motivation increased with years of study among learners of Arabic. Therefore, we hypothesis: 
H1a: SM effects are significantly different based on the study years.

H1b: Motivation shows a significantly different effect based on years of study.

$\mathrm{H} 2$ : $\mathrm{SM}$ is significantly correlated with motivation.

H3a: SM can positively affect the learning outcome.

H3b: Motivation can positively affect the learning outcome.

\section{Research Method}

\section{Research Design}

The study was conducted with a quantitative survey methodology by distributing a questionnaire to six public universities in Malaysia. A total of 317 university undergraduate students participated in the current study by employing and a Motivated Strategies for Learning Questionnaire (MSLQ) (Pintrich et al., 1991) and Social Media Usage Questionnaire (Monachesi et al., 2008). Hypothesis testing was done by using inferential analysis in SPSS Version 22.

\section{Participants}

The sample population in this study included 317 students who were pursuing a Malay Bachelors' degree (Years 1-4) and also learning the Arabic language in 6 universities, i.e., University Kebangsaan Malaysia (UKM), University of Malaya (UM), Universiti Sultan Zainal Abidin (UniSZA), International Islamic University Malaysia (IIUM), Universiti Putra Malaysia (UPM) and the Universiti Sains Islam Malaysia (USIM). The researchers collected the demographic information of all students and noted that the population included $14.2 \%$ males and $85.8 \%$ females. A majority of the participants were in their Second Year $(50.9 \%)$, followed by those in their first year $(21.7 \%)$, Fourth Year $(15.6 \%)$ or Third year $(11.8 \%)$. Furthermore, $90 \%$ of these students used social media for $>5$ hours every day. Table 1 presents the profiles of the respondents based on their demographic characteristics.

Table 1 Profiles of Respondents according to Demographic Characteristics $(N=317)$

\begin{tabular}{llll}
\hline Variables & Characteristics & Frequency & Percent (\%) \\
\hline Gender & Male & 45 & 14.2 \\
& Female & 272 & 85.8 \\
Year of study & Year 1 & 69 & 21.7 \\
& Year 2 & 161 & 50.9 \\
& Year 3 & 38 & 11.8 \\
Usage of SM & Year 4 & 49 & 15.6 \\
& Monthly & 22 & 6.9 \\
& Once a week & 10 & 3.2 \\
& More than 5 hours per- & 89.9 \\
\hline
\end{tabular}




\section{Instruments}

The researchers used a questionnaire as their survey instrument in this study. This questionnaire included 3 sections, i.e., Section A which asked the respondents to fill their demographic and personal details related to this study. This section included 3 questions, i.e., (1) The Gender of the learner; (2) Level of Study of the Learner; and (3) Academic achievements of the Learner. The second section used the data language technologies suggested by Monachesi et al. (2008) for understanding the SMU levels of the Arabic learners for formal or informal learning. Section 3 included questions related to motivation. These questions were adopted from a Motivated Strategies for Learning Questionnaire (MSLQ) that included factors like Task-Value (TV), Self-Efficacy (SE) and Goal Orientation (GO). Since the majority of the participants who were learning Arabic were Malayan, the researchers noted that some of the students could not understand the English language properly. Hence, this questionnaire was constructed in the Malay language for avoiding any errors regarding the participants' comprehension of all questions and their answers.

\section{Pilot study}

The researchers carried out a pilot study which included 35 students to determine the implementation of the instruments and detect any issues. However, no further review was needed and the survey instrument was not modified. The reliability of this questionnaire was determined using Cronbach's Alpha value for all dimensions. This value ranged between 0.759 and 0.846 . The motivation dimensions ranged between 0.736 and 0.859 . These values indicated a very high level of reliability and internal consistency.

\section{Data Analysis}

The researchers analysed all data using the SPSS ver. 22 and SmartPLS 3 software. They used the inferential and descriptive statistical analysis for analysing all data and investigating the relationship between the learners' SMU and their motivation levels. The data and the analysis of the SMU and motivation were supported using the 5-point Likert scale. The researchers used 3 different statistical processes for assessing the responses of the respondents. Initially, they analysed the research questions using the descriptive statistics for determining the frequency and the percentage, followed by the inferential statistics for determining the different results based on the year of study of the learners and the relationship between the SMU and Motivation. Lastly, they used the Structural Equation Modelling (SEM) process along with SmartPLS 3 for determining the effect of SMU and Motivation on the academic results of the learners (GPA). 


\section{Findings}

Test of Hypotheses: H1a, H1b.

\begin{tabular}{|c|c|c|c|c|c|c|}
\hline & & Sum of Squares & $\mathrm{df}$ & Mean Square & $\mathrm{F}$ & Sig. \\
\hline \multirow[t]{3}{*}{ SE } & Between Groups & 3.478 & 3 & 1.159 & 4.004 & .008 \\
\hline & Within Groups & 90.616 & 313 & .290 & & \\
\hline & Total & 94.094 & 316 & & & \\
\hline \multirow[t]{3}{*}{ TV } & Between Groups & 2.113 & 3 & .704 & 2.888 & .036 \\
\hline & Within Groups & 76.325 & 313 & .244 & & \\
\hline & Total & 78.438 & 316 & & & \\
\hline \multirow[t]{3}{*}{$\mathrm{O}$} & Between Groups & 2.389 & 3 & .796 & 4.061 & .007 \\
\hline & Within Groups & 61.370 & 313 & .196 & & \\
\hline & Total & 63.759 & 316 & & & \\
\hline \multirow[t]{3}{*}{ Motivation } & Between Groups & 2.514 & 3 & .838 & 4.664 & .003 \\
\hline & Within Groups & 56.233 & 313 & .180 & & \\
\hline & Total & 58.747 & 316 & & & \\
\hline \multirow[t]{3}{*}{ SMI } & Between Groups & 1.368 & 3 & .456 & 1.530 & .207 \\
\hline & Within Groups & 93.247 & 313 & .298 & & \\
\hline & Total & 94.615 & 316 & & & \\
\hline \multirow[t]{3}{*}{ SMF } & Between Groups & 2.582 & 3 & .861 & 1.602 & .189 \\
\hline & Within Groups & 168.157 & 313 & .537 & & \\
\hline & Total & 170.739 & 316 & & & \\
\hline \multirow[t]{3}{*}{ SM } & Between Groups & 1.180 & 3 & .393 & 1.301 & .274 \\
\hline & Within Groups & 94.694 & 313 & .303 & & \\
\hline & Total & 95.875 & 316 & & & \\
\hline
\end{tabular}

Table 1 presents the results of the one-way ANOVA test which was carried out for comparing the differences between Motivation using factors like Self-Efficacy (SE), Goal Orientation (GO), and Task Value (TV) and the SMU using factors like Social Media usage for Formal learning (SMF), and the Social Media usage for Informal learning (SMI) for students in different study years. Motivation showed a significant difference amongst students in different study years $(\mathrm{F} 3.313=4.664 ; \mathrm{P}=0.003)$. Similarly, $\mathrm{SE}$ also showed a significant difference amongst the students in different study years $(\mathrm{F} 3.313=4.004 ; \mathrm{p}=0.008)$, TV $(\mathrm{F} 3.313=2.888 ; \mathrm{p}=0.036)$ and GO (F3.313 = 4.061; $=0.007)$. However, SMU did not show a significant difference with regards to the study years $(\mathrm{F} 3.313=1.301 ; \mathrm{p}=0.274)$ or $(\mathrm{F} 3.313$ $=1.530 ; p=0.207)$ and SMF $(F 3.313=1.602 ; p=0.189)$. Therefore, the researchers rejected the H1a; while they supported the H1b. 
Table 2: Tukey HSD for or Motivation in different years of study

\begin{tabular}{|c|c|c|c|c|c|c|c|}
\hline \multirow{3}{*}{$\begin{array}{l}\text { Dependen } \\
\text { t Variable }\end{array}$} & \multirow{3}{*}{$\begin{array}{l}\text { (I)Year } \\
\text { of } \\
\text { Study }\end{array}$} & \multirow{3}{*}{$\begin{array}{l}\text { (J) Year of } \\
\text { Study }\end{array}$} & \multirow{3}{*}{$\begin{array}{l}\text { Mean } \\
\text { Difference } \\
(\mathrm{I}-\mathrm{J})\end{array}$} & \multirow[b]{3}{*}{ Std. Error } & \multirow[b]{3}{*}{ Sig. } & \multicolumn{2}{|c|}{$\begin{array}{l}\text { 95\% Confidence } \\
\text { Interval }\end{array}$} \\
\hline & & & & & & Lower & Upper \\
\hline & & & & & & Bound & Bound \\
\hline \multirow[t]{3}{*}{ SE } & \multirow[t]{3}{*}{ Year 1} & Year 2 & $.22224^{*}$ & .07024 & .009 & .0408 & .4037 \\
\hline & & Year 3 & .10964 & .11312 & .767 & -.1825 & .4018 \\
\hline & & Year 4 & .00173 & .10918 & 1.000 & -.2803 & .2837 \\
\hline \multirow[t]{3}{*}{ TV } & \multirow[t]{3}{*}{ Year 1} & Year 2 & .14224 & .06447 & .124 & -.0243 & .3088 \\
\hline & & Year 3 & .12214 & .10382 & .642 & -.1460 & .3903 \\
\hline & & Year 4 & -.08033 & .10020 & .854 & -.3391 & .1785 \\
\hline \multirow[t]{3}{*}{ GO } & \multirow[t]{3}{*}{ Year 1} & Year 2 & $.17757^{*}$ & .05781 & .012 & .0283 & .3269 \\
\hline & & Year 3 & .05685 & .09310 & .929 & -.1836 & .2973 \\
\hline & & Year 4 & -.01649 & .08985 & .998 & -.2486 & .2156 \\
\hline \multirow{3}{*}{$\begin{array}{l}\text { Motivatio } \\
\mathrm{n}\end{array}$} & \multirow[t]{3}{*}{ Year 1} & Year 2 & $.18604^{*}$ & .05533 & .005 & .0431 & .3290 \\
\hline & & Year 3 & .09059 & .08911 & .740 & -.1396 & .3208 \\
\hline & & Year 4 & -.00925 & .08601 & 1.000 & -.2314 & .2129 \\
\hline
\end{tabular}

*. The mean difference is significant at the 0.05 level.

Table 1 presented the significant differences noted in the various factors related to Motivation like SE, GO, and TV with regards to the different study years. Furthermore, the researchers conducted a Tukey post-hoc test which indicated that students in Year 4 showed the highest statistically significant effect of motivation, followed by the Year 1 students. Year 2 students reported the lowest effect of motivation. Additionally, Year 1 students showed the highest statistically-significant effect of SE $(p=0.031)$, followed by Year 4 students. The year 2 students showed the lowest effect of SE. The Tukey test results for the TV and GO factors were noted in the following order, i.e., Years 4, 1, 3 and 2, respectively. The results indicated that the study year significantly affected the motivation (based on factors like SE, GO, and TV) of the Arabic learners. The students in Years 4 and 1 showed a higher motivation effect, whereas Year 2 students noted the lowest effect of motivation.

\section{Test of $\mathbf{H 2}$}

Table 3 Pearson Correlation Table

\begin{tabular}{llrr}
\hline & SMU & \multicolumn{2}{r}{ Motivation } \\
\hline SMU & Pearson & 1 & $.499^{* *}$ \\
& Correlation & & .000 \\
& Sig. (2-tailed) & & 317 \\
N & & 317 & 317 \\
\hline
\end{tabular}

**. Correlation is significant at the 0.01 level (2-tailed). 
As show in Table 3, Pearson Correlation Table indicated the correlation between SMU and Motivation. There was a significant correlation between SMU and Motivation $(r=.50, p<.01)$. The Correlation coefficient of $r=.50$ indicated that the correlation strength between SMU and Motivation is medium. Therefore, $\mathrm{H} 2$ is supported.

Test of H3a, H3b

Table 4 T-statistics of the influence Motivation on Academic Performance

\begin{tabular}{ccccccc}
\hline & Regression & & & & \\
\cline { 1 - 4 } $\begin{array}{c}\text { Dependent } \\
\text { variable }\end{array}$ & & $\begin{array}{c}\text { Independent } \\
\text { variables }\end{array}$ & Estimate $(\beta)$ & $\mathrm{T}$ & $\mathrm{P}$ & $\mathrm{R}^{2}$ \\
\cline { 1 - 5 } GPA & $<---$ & $\mathrm{SE}$ & .17 & 3.17 & .00 & .042 \\
GPA & $<---$ & $\mathrm{TV}$ & -.04 & .35 & .73 & \\
GPA & $<---$ & GO & .10 & .89 & .37 & \\
\hline
\end{tabular}

Note: $\mathrm{SE}=$ Self-efficiency; $\mathrm{TV}=$ Task Value; $\mathrm{O}=$ Goal orientation; $\mathrm{GPA}=$ Academic Achievement

Table 4 presents the results of the SEM analysis using PLS. The results showed T-statistics values above 1.96 for the relationship between SE and GPA $(\beta=0.17, t=3.17, p<0.05)$. This indicated that the SE significantly affected the GPA of the learners. Furthermore, the Task value $(\beta=-0.04, t=0.35, p>0.05)$ and Goal orientation $(\beta=0.10, t=0.89, p>0.05)$ did not show $a$ statistically significant effect on the academic achievements of the learners at $p>0.05$. Hence, H3a was rejected.

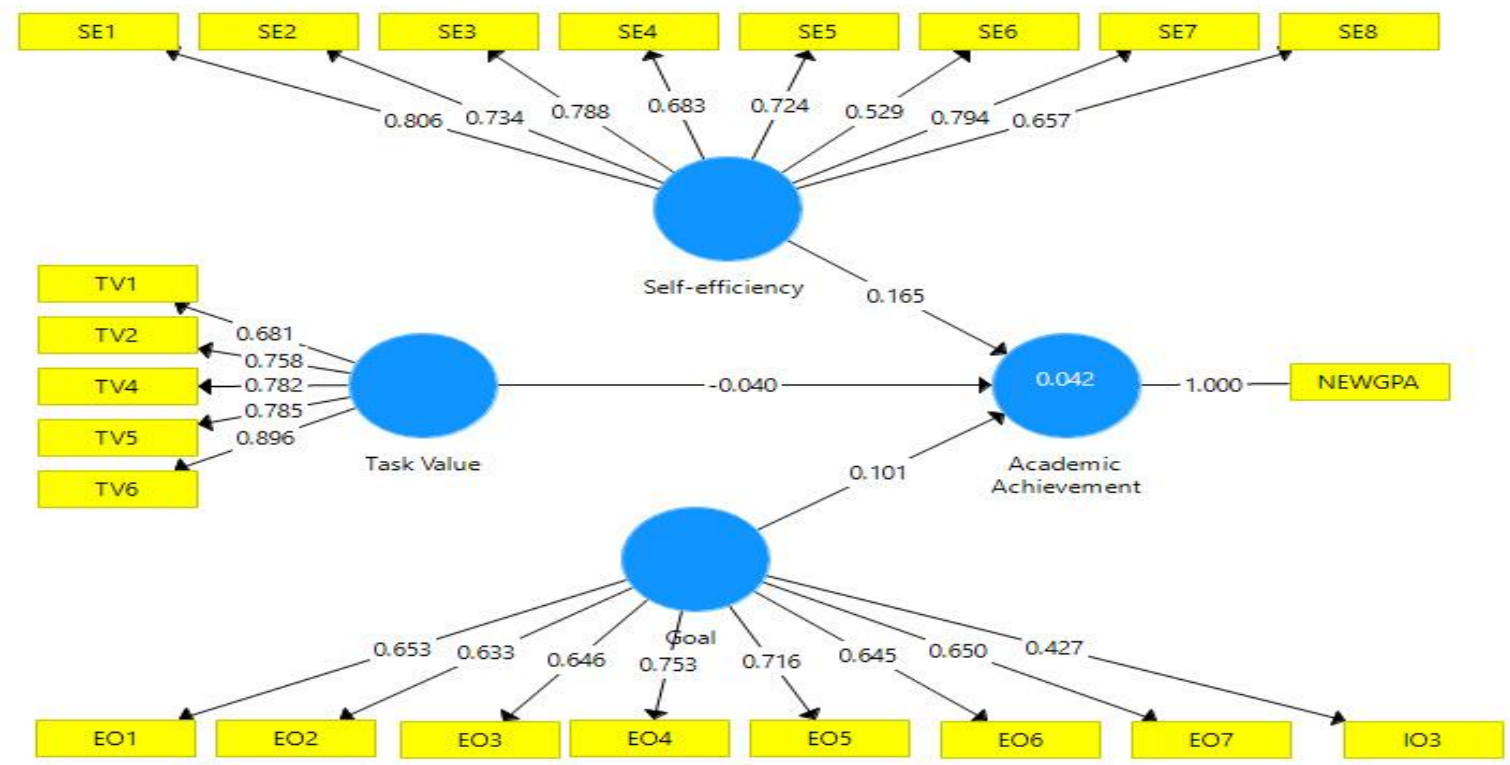

Figure 3. SEM Model for the influence of Motivation on academic achievement

Figure 3 visually showed the influences of dimensions motivation (SE, TV, and Go) on Academic achievement. As Figure 4 clarified, the value of $\mathrm{R}^{2}$ is .042 which means only $4.2 \%$ of academic achievement was caused by motivation variables. 
Table 5: T-statistics of influence of SMU on academic achievement

\begin{tabular}{ccccccc}
\hline & Regression & & & & \\
\cline { 1 - 2 } $\begin{array}{c}\text { Dependent } \\
\text { variable }\end{array}$ & & $\begin{array}{c}\text { Independent } \\
\text { variables }\end{array}$ & Estimate $(\beta)$ & T & $\mathrm{P}$ \\
\hline GPA & $<---$ & SMI & .19 & 1.68 & .10 \\
GPA & $<---$ & SMF & -.04 & .36 & .72 \\
\hline
\end{tabular}

Note: $\mathrm{SMI}=$ Social media usage for Informal Learning; $\mathrm{SMF}=$ Social media usage for Formal Learning; GPA= Academic Achievement

Table 5 presents the SEM analysis results with SmartPLS. The results indicated that the Tstatistics value lower than 1.96 highlighted the relationship between the SMI and student achievements $(\beta=0.19, \mathrm{t}=1.68, \mathrm{p}>0.05)$ and the SMF and achievements $(\beta=-0.04, \mathrm{t}=0.36$, $\mathrm{p}>0.05$ ) are not statistically significant influence in GPA. Hence, it was concluded that the SMI and the SMF showed no significant effect on the academic performance of the learners. Thus, the researchers rejected $\mathrm{H} 3 \mathrm{~b}$.

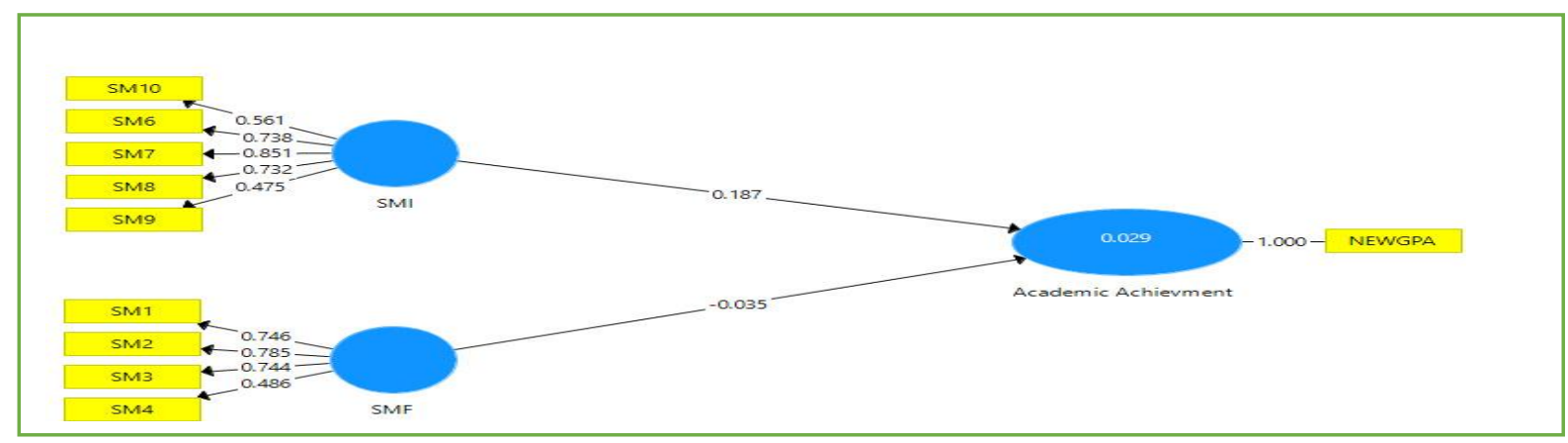

Figure 4: SEM Model for the influence of SMU on academic achievement

As indicated in Table 5, SMI and the SMF showed no significant effect on the academic Performance of the learners. Figure 4 was visually explained the value of $\mathrm{R}^{2}$ is .029 which clearly proved the no significant effect of SMU on academic performance.

\section{Discussion}

In recent years, face-to-face is no more core learning methods, and blended learning was taking essential place in global education. More and more students preferred neither fully faceto-face nor fully online for teaching and learning. Following the education trend, a huge number of studies intended to study about the effectiveness of social media on learning (Gardner 2006; Dabbagh and Kitsantas 2012; Tu et al., 2015; Akbari et al., 2016; KeHua 2016; Matzat and Vrieling 2019; Chawinga 2017; Google (Firm) Canvas8 (Firm) 2019), and social media used in learning enhance motivation (Bugeja 2006; Malerba 2015; Akbari et al., 2016). Here, the researchers stated that the study year of the students played a vital role in affecting 
their motivation (and other relative factors like SE, TV and GO); however, they did not affect the social media usage amongst the Arabic learners. These results indicated that the study year did not influence the SMI and the SMF of Arabic learners. On the other hand, the findings also indicated that SE, TV and the GO varied significantly for the Year 1-4 learners. It was interesting to note that the Year 1 and 4 students showed higher SE, TV and GO levels, while the Year 3 and 2 learners showed lower results. These results presented the implication of policy implementation and the research studies in future. One implication indicated that these results helped in determining why the students in the $2^{\text {nd }}$ and $3^{\text {rd }}$ years showed lower TV, SE, and GO levels, and how to improve these levels.

Furthermore, SMU significantly affected the motivation levels of the learners. Thus, SMU strongly predicts the motivation, and it was seen that when the students with a higher SMU pursued the learning of the Arabic language, their motivation levels were very high. Similarly, some studies (Bugeja 2006; Malerba 2015; Akbari et al., 2016) proposed that SMU enhances learners' motivation.

However, GO and TV did not affect the academic performance of these learners, similar to the SMI and SMF values. It must be noted that these Arabic learners showed a high SM frequency i.e., $>5 \mathrm{~h}$ per day. These findings were inconsistent in comparison to those presented earlier (Gardner 2006; Ziegler 2007; Dabbagh and Kitsantas 2012; Tu et al., 2015; Akbari et al., 2016; KeHua 2016; Matzat and Vrieling 2019; Chawinga 2017; Google (Firm) Canvas8 (Firm) 2019). Furthermore, SE was the sole factor which affected academic achievement. The current findings were consistent with the results presented in the earlier studies (Dörnyei and Ushioda 2013).

\section{Implication of this study}

Both implications for theory and implications for the practice of the study are discussed and presented in the section. This study further specifies the discussion regarding SMU and motivation among Arabic learners. Numerous literature reviews have discussed the linkages between SMU and motivation, but none have looked at the linkages as outlined by the framework developed for this study. This study was able to provide some useful information on the level of Malaysian undergraduate Arabic learners' SMU and motivation. Based on Media system dependency theory (MSD) (Ball - Rokeach, 2008), the researchers assumed social media usage indirect effect on motivation, and motivation direct effect on social media usage. The findings of the current study are consistent with Media system dependency theory (MSD). Hence, this study provides fresh empirical evidence to support the Media system dependency theory (MSD) which presents a statistically significant positive correlation between social media usage and motivation in the Arabic language learning context in Malaysia. In addition, this study provides some implications for the Ministry of Education (MOE) Malaysia, practitioners including Arabic language department policymakers in universities, researchers, teachers, students, and parents as well. Based on the finding of this study, the Ministry and higher education institutes may identify new teaching and learning strategies for both course instructors and students.

\section{Conclusion}

This study did not observe a statistically significant influence of the SMI or SMF on the 
academic performance of the learners; however, the researchers stated that more investigation needs to be conducted in these subjects. A further investigation could help different researchers enhance the quality of the Arabic language which is taught to the learners. It could additionally help in determining better lectures and indicators which helped in using better technology while teaching the Arabic language. As suggested in some earlier studies (Dabbagh and Kitsantas 2012), the researchers used social media tools related to Arabic language teaching, as described in Table 6. With this in mind, faculty can collaborate with instructional designers to identify opportunities to leverage online and social media learning environments. As mentioned above, research into these areas could help in determining better lectures and indicators which control the abilities and needs of these students, so that their skills can be fostered for the $21^{\text {st }}$ century. 
Table 6: Social media tools facilitate Arabic language learning

\begin{tabular}{|c|c|c|c|}
\hline & $\begin{array}{l}\text { (Level1) } \\
\text { Personal information management }\end{array}$ & $\begin{array}{c}\text { (Level 2) } \\
\text { Social interaction and collaboration }\end{array}$ & $\begin{array}{l}\text { (Level 3) } \\
\text { Information aggregation and } \\
\text { management }\end{array}$ \\
\hline $\begin{array}{l}\text { WhatsApp, } \\
\text { Facebook, } \\
\text { WeChat }\end{array}$ & $\begin{array}{l}\text { The teacher invited pupils to employ social } \\
\text { network tools such as groups of WhatsApp, } \\
\text { Facebook, and give assignments and task in } \\
\text { the group in the Arabic language. }\end{array}$ & $\begin{array}{l}\text { Instructors encourage students to discuss in Arabic } \\
\text { in those groups and they may ask any questions they } \\
\text { met, anybody in the group may share open main } \\
\text { opinions in Arabic. }\end{array}$ & $\begin{array}{l}\text { The instructor demonstrates how to } \\
\text { aggregate information and notice, how } \\
\text { to check status and post status in } \\
\text { Arabic. }\end{array}$ \\
\hline MOOCs & $\begin{array}{l}\text { Instructor or parents introduce MOOCs to } \\
\text { students. Students can register as users and } \\
\text { login to use the huge online course for free. }\end{array}$ & $\begin{array}{l}\text { Instructors show to students how to enroll in the } \\
\text { Arabic language course, and encourage students to } \\
\text { leave a message in the discussion area if they got any } \\
\text { misunderstanding in the course and discuss with } \\
\text { others in the same online course. }\end{array}$ & $\begin{array}{l}\text { Instructors demonstrate how to } \\
\text { manage the online courses, such as a } \\
\text { review or continue the course learning. } \\
\text { How to get the certificate if necessary. }\end{array}$ \\
\hline blog & $\begin{array}{l}\text { The teacher inspires pupils to employ social } \\
\text { media such as blogs to set learning objectives } \\
\text { and design course projects and tasks in the } \\
\text { Arabic language that engages them in SRLs } \\
\text { Goal setting and planning and Environmental } \\
\text { structuring. }\end{array}$ & $\begin{array}{l}\text { The teacher inspires pupils to facilitate the blog } \\
\text { comment feature to permit instructor and peers } \\
\text { response thus allowing standard interaction and } \\
\text { sharing in the Arabic language to foster the use of } \\
\text { social media in informal Arabic learning and finally } \\
\text { achieved assist formal learning performances' goals. }\end{array}$ & $\begin{array}{l}\text { The teacher shows how to arrange a } \\
\text { blog to attract extra content and add the } \\
\text { blog to RSS aggregation services in } \\
\text { Arabic. }\end{array}$ \\
\hline YouTube & $\begin{array}{l}\text { The teacher inspires pupils to employ } \\
\text { YouTube to subscribe some benefit channels } \\
\text { or programs in Arabic language, such as القرآن، الثريعة و الحياة، سلسلة اللغة العربية من قناة } \\
\text { الجزيرة، و محاضرات } \\
\text { To foster informal Arabic learning using social } \\
\text { media and Seeking information strategy. }\end{array}$ & $\begin{array}{l}\text { The teacher inspires pupils to facilitate the do } \\
\text { comment under the video in the Arabic language to } \\
\text { engage students help-seeking strategy. }\end{array}$ & $\begin{array}{l}\text { The teacher shows how to gather } \\
\text { media from several sources and against } \\
\text { some false channels to foster students' } \\
\text { self-evaluating strategy. }\end{array}$ \\
\hline
\end{tabular}




\begin{tabular}{llll}
\hline Google & The teacher inspires pupils to employ Google & The teacher inspires pupils to facilitate calendar & The teacher shows how to record \\
Calendar & Calendar for individual scheduling and record & sharing features to permit comments and partnership personal and group calendars to \\
it in the Arabic language; it would be foster & to complete course tasks in the Arabic language. & $\begin{array}{l}\text { support student self-evaluation } \\
\text { students' Keeping records and monitoring }\end{array}$ & concerning time preparation and \\
strategy. & & management.
\end{tabular}


Declaration of Conflicting Interest

All co-authors have seen and agree with the contents of the manuscript. We certify that the submission is original work and is not under review at any other publication.

Funding Acknowledgement

We would like to acknowledge University of Malaya for funding through Project No. (RP005A-14HNE) and (CG14-2014) that supported this study.

\section{References}

Ainon, M., \& Abdullah, H. (2005). Guru sebagai Pendorong Dalam Darjah [Teachers as Motivators in Classroom]. Bentong, MY: PTS Profesional Pubilising Sdn. Bhd.

Akbari, E., Naderi, A., Simons, R.-J., \& Pilot, A. (2016). Student engagement and foreign language learning through online social networks. Asian-Pacific Journal of Second and Foreign Language Education, 1(1), 1-22. https://doi.org/10.1186/s40862-016-0006-7

Awang, N. A., Mohamed, M. H., \& Sulaiman, R. (2013). Enhancing Arabic Speaking Skills among Malay Students through Group Work Activities. International Journal of Humanities and Social Science, 3(21), 212-219.

Bakar, K. A., Sulaiman, N. F., \& Rafaai, Z. A. M. (2010). Self-Determination Theory and motivational orientations of Arabic learners: A principal component analysis. GEMA Online® Journal of Language Studies, 10(1), 71-86.

Ball-Rokeach, S. J. (2010). Media System Dependency Theory. The International $\begin{array}{lllll}\text { Encyclopedia of } & \text { Communication. } & 2 & \text { (2), } & \text { 233-258. }\end{array}$ doi:10.1002/9781405186407.wbiecm051

Bawabat Ataaleem. (2017). Retrieved on 18/1/2018 at:http://www.taleemgate.com/t 703

Brooks, D., \& Pomerantz, J. (2017). ECAR study of undergraduate students and information technology, 2017 [Internet]. EDUCAUSE Center for Analysis and Research, Louisville, CO.[cited 25 Sept 2018]. Available from: https://www. educause. edu/ecar.

Bugeja, M. (2006). Facing the Facebook. Chronicle of Higher Education, 52 (21), C1.

Chawinga, W. D. (2017). Taking social media to a university classroom: teaching and learning using Twitter and blogs. International Journal of Educational Technology in Higher Education, 14(1), 3. doi:10.1186/s41239-017-0041-6

Dabbagh, N., \& Kitsantas, A. (2012). Personal Learning Environments, social media, and selfregulated learning: A natural formula for connecting formal and informal learning. The Internet and Higher Education, 15(1), 3-8. doi:10.1016/j.iheduc.2011.06.002

Dana, C. G. (2019). ECAR Study of Undergraduate Students and Information Technology. EDUCAUSE Center for Analysis and Research, Louisville, CO. Available from: https://www. educause. edu/ecar.

Dabbagh, N., \& Kitsantas, A. (2012). Personal Learning Environments, social media, and selfregulated learning: A natural formula for connecting formal and informal learning. The Internet Higher Education, 15(1), 38. https://doi.org/10.1016/j.iheduc.2011.06.002.

Dörnyei, Z. (2014). The psychology of the language learner: Individual differences in second language acquisition. London: Routledge. doi:10.4324/9781410613349 
Dörnyei, Z. (2008). Motivation strategies in the language classroom: Ernst Klett Sprachen.

Dörnyei, Z., Ushioda, E. (2011). Teaching and Researching: Motivation. London: Routledge, https://doi.org/10.4324/9781315833750

Galanek, J., Gierdowski, D., \& Christopher Brooks, D. (2018). ECAR study of undergraduate students and information technology 2018, EDUCAUSE Center for Analysis and Research, Louisville, CO. Available from: https://www. educause. edu/ecar.

Gardner, H. (2006). The Development and Education of the Mind. London: Routledge, https://doi.org/10.4324/9780203019689

Ghani, K. A., Yusof, N. M. R. N., Baharuddin, H., Yamat, H., Ahmad, Z., \& Abdullah, I. (2011). Development of a learning module on Arabic Language Skills Outside of the Classroom. Procedia-Social and Behavioral Sciences, 18, 154-162. https://doi.org/10.1016/j.sbspro.2011.05.023

Ghenghesh, P. (2010). The Motivation of Learners of Arabic: Does it Decrease with Age? Journal of Language Teaching and Research, 1(3), 235-249. doi:10.4304/jltr.1.3.

Google (Firm) Canvas8 (Firm). (2019). Future of the classroom: emerging trends in K-12 education: global edition. Available from:

http://services.google.com/fh/files/misc/future of the classroom_emerging trends in k12 education.pdf

Ismail, A. R. B. H. (1993). The teaching of Arabic in the Faculty of Islamic Studies in the National University of Malaysia (Doctoral dissertation, University of Salford, Salford, UK). Available from: http://usir.salford.ac.uk/id/eprint/14807/

Jordan Times (2010), retrieved on 18/1/2018 at:https://www.edarabia.com/12895/number-ofmalaysian-students-in-jordan-at-13-year- high/

Junco, R., Elavsky, C. M., \& Heiberger, G. (2013). Putting twitter to the test: Assessing outcomes for student collaboration, engagement and success. British Journal of Educational Technology, 44(2), 273-287. https://doi.org/10.1111/j.14678535.2012.01284.x

Karbakhsh, R., \& Safa, M. A. (2020). Basic Psychological Needs Satisfaction, Goal Orientation, Willingness to Communicate, Self-efficacy, and Learning Strategy Use as Predictors of Second Language Achievement: A Structural Equation Modeling Approach. Journal of Psycholinguistic Research, 1(20), 7-14. https://doi.org/10.1007/s10936-020-09714-7

Haron, S. C., Ahmad, I. S., Mamat, A., \& Mohamed, I. H. A. (2010). Understanding ArabicSpeaking Skill Learning Strategies Among Selected Malay Learners: A Case-Study At The International Islamic University Malaysia (IIUM). Contemporary Issues in Education Research (CIER), 3(8), 9-20. doi:10.19030/cier.v3i8.222

Malerba, M. L. (2015). Social networking in second language learning: informal online interactions (Doctoral dissertation, Universitat Oberta de Catalunya, Barcelona, Spain). Available from:https://dialnet.unirioja.es/servlet/tesis?codigo $=177432$

Matzat, U., \& Vrieling, E. M. (2019). Self-regulated learning and social media - a "natural alliance"? Evidence on students' self-regulation of learning, social media use, and student-teacher relationship. Learning, Media and Technology, 41(1), 73-99. doi:10.4324/9781315121697-5

Monachesi, P., Mossel, E., Posea, V., Simov, K., Osenova, P., Tincheva, A., \& Laskova, L. 
(2008). LTfLL-D6. 1: Social and informal learning support design. (Report No.

LTfLL -2008-212578). Language Technologies for Lifelong Learning, Heerlen, NL, Available from:

https://www.academia.edu/30695289/LTfLL_D6_1_Social_and_informal_learning_s upport design

Morrow, J. A., \& Castleton, B. (2007). The impact of globalization on the Arabic language. Intercultural Communication Studies, 16(2), 202-220.

Pintrich, P. R., Garcia, T., McKeachie, W. J., \& Smith, D. A. (1991). Motivated strategies for learning questionnaire: Regents of the University of Michigan. Ann Arbor, US. doi:10.1037/t09161-000

Sehatzadeh, A., \& Le-May Sheffield, S. (2014). Survey of faculty use of online technologies 2013. Retrieved from Center for learning and teaching, Dalhousie University Killam Library, Halifax, Canada. https://www.dal.ca/content/dam/dalhousie/pdf/dept/clt/elearning/Faculty\%20Write\%20up\%20for\%20dissemination_FINAL_Sept_29.pdf.

Smith, E. E. (2017). Social media in undergraduate learning: categories and characteristics. International Journal of Educational Technology in Higher Education, 14(1), 12. doi:10.1186/s41239-017-0049-y

Tu, C. H., Yen, C. J., \& Sujo-Montes, L. E. (2015). Personal learning environments and selfregulated learning. In Media rich instruction (pp. 35-48). Springer, Cham. https://doi.org/10.1007/978-3-319-00152-4_3

Xuan, D., Ismail, W., Zailaini, M., \& Hussin, Z. (2014). Achievement Motivation Across Gender and Academic Level of Students at Islamic Institute of Education in China. OIDA International Journal of Sustainable Development,7(12), 83-94. Available at SSRN: https://ssrn.com/abstract=2573093

Yusri, G., Rahimi, N. M., Shah, P. M., \& Wan Haslina, W. (2012). Motivation in learning oral Arabic among students with different prior experiences and gender. Pertanika Journal Social Science \& Humanities, 20(3), 669-682.

Ziegler, S. G. (2007). The (mis) education of Generation M. Learning, Media and Technology, 32(1), 69-81. doi:10.1080/17439880601141302 余可华. (2016). 多种现代技术支持的第二语言学习. 海外华文教育(5), 708-720. 